\title{
A 10 Years Comparative Study to Assess Trends in Seroprevalence of Transfusion Transmitted Infections among Blood Donors at Gwalior, India
}

\author{
Dharmesh Chandra Sharma1*, Sunita Rai1, Savita Bharat², Sudha Iyenger1, Shruti Gupta1, \\ Bharat Jain ${ }^{1}$ \\ ${ }^{1}$ Department of Pathology, Blood Bank, Gajra Raja Medical College, Gwalior, India \\ ${ }^{2}$ Department of Microbiology, Gajra Raja Medical College, Gwalior, India \\ Email: ${ }^{*}$ dr dharmesh sharma@yahoo.com
}

Received 12 May 2014; revised 8 June 2014; accepted 27 June 2014

Copyright (C) 2014 by authors and Scientific Research Publishing Inc.

This work is licensed under the Creative Commons Attribution International License (CC BY). http://creativecommons.org/licenses/by/4.0/

\section{(c) (i) Open Access}

\section{Abstract}

Introduction: Transfusion Transmitted Infections (TTIs) threaten safety of the recipients and the community as a whole and are the subject of real concern worldwide. Aims and Objectives: To know the prevalence of transfusion transmitted infections amongst the blood donors, to evaluate the changing trends of TTIs and to compare these observations within the study as well as with the other relevant studies. Place and Duration of Study: This study was carried out at Blood Bank, Department of Pathology, Gajra Raja Medical College, Gwalior, India, from January 2004 to December 2013 (ten years). Materials and Methods: In this study 122,006 voluntary and replacement donations were screened for TTIs; HIV, HBV, HCV, Syphilis, Malaria and their seroprevalence was calculated. Further study was divided in Group "A" (from 2004 to 2008) and Group "B" (from 2009 to 2013) to compare the results. Results: Out of total 122,006 blood units collected, 79,750 (65.3\%) were voluntary and 42,256 (34.7\%) were replacement donors. The seropositivity of TTIs in the entire study, in group " $A$ " and in Group "B" was 3.26\% $(3985 / 122,006)(p=0.000005), 2.25 \%$ $(1238 / 54,874)(p=0.000005)$ and $4.09 \%(2747 / 67,123)(p=0.000005)$ respectively. In Group "A" and "B" seroprevalence of HIV, HBV, HCV, Syphilis and Malaria was 0.29\%, 1.16\%, 0.61\%, 0.06\%, $0.11 \%$ and $0.13 \%, 3.15 \%, 0.24 \%, 0.17 \%, 0.03 \%$ respectively. Conclusion: Our study concluded that there was significant increase in seroprevalence of $\mathrm{HBV}$ and syphilis whereas decreasing pattern in HIV, HCV and Malaria was observed in last five years as compared to previous five years among the blood donors.

\footnotetext{
"Corresponding author.
}

How to cite this paper: Sharma, D.C., Rai, S., Bharat, S., Iyenger, S., Gupta, S. and Jain, B. (2014) A 10 Years Comparative Study to Assess Trends in Seroprevalence of Transfusion Transmitted Infections among Blood Donors at Gwalior, India. Open Journal of Blood Diseases, 4, 24-32. http://dx.doi.org/10.4236/ojbd.2014.42004 


\section{Keywords}

\section{Transfusion Transmitted Infections (TTIs), Blood Donor (BD), Human Immunodeficiency Virus (HIV), Hepatitis B Virus (HBV), Hepatitis C Virus (HCV), Syphilis and Malaria}

\section{Introduction}

Transfusion of blood and/or its components is a life saving measure but at the same time it has life threatening hazards also [1]. Blood and/or its components are not $100 \%$ safe for transfusion. With each and every unit of blood there is a risk of transfusion associated problems including transmission of transfusion transmitted infections (TTIs) [2] which includes Human Immunodeficiency Virus (HIV), Hepatitis B Virus (HBV), Hepatitis C Virus (HCV), Syphilis, Malaria and many more infections. The economic cost of the failure to control the transmission of the infections includes increased requirement of medical care, high level of dependency and the loss of productive labour force and places heavy burden on already overstretched health and social services on national economy [3]-[5].

India has a population of more than 1.2 billion with 5.7 (reduced to 2.5) million Human Immunodeficiency Virus (HIV) positive, 43 million HBV-positive and 15 million HCV-positive people [6]. The risk of transfusion associated transmission of these viruses may be alarming due to high seroprevalence of HIV, HCV and HBV (0.5\%, $0.4 \%$ and $1.4 \%$ respectively) among blood donors [7]. Transfusion medicine apart from being important for the treatment of each patient also has a great public health importance [8]. Discovery of these hazards brought a dramatic change in attitude of physicians and patients about the transfusion of blood [9]. As per guidelines of National AIDS Control organization (NACO) of India, it is mandatory to test each and every blood unit for HIV, anti HCV, HbsAg, Syphilis and Malaria [10].

India is the second most populous nation in the world. The Indian subcontinent is classified as an intermediate Hepatitis B Virus (HBV) endemic (HBsAg carriage 2\% - 7\%) zone and has the second largest global pool of chronic HBV infections [11] causing death due to chronic hepatitis, cirrhosis liver and hepatocellular carcinoma [12].

Aim of this study is to estimate the seroprevalance of Transfusion Transmitted Infections (TTIs) among the voluntary and relative donors over a period of ten years at a large blood bank in Gwalior, Madhya Pradesh, India and to evaluate the trends of TTIs. These observations were compared within the study as well as with the other relevant studies.

\section{Materials and Methods}

This study was carried out at blood bank, department of Pathology, Gajra Raja Medical College, Gwalior (Madhya Pradesh), India. Donors were screened with trained personnel after satisfactory answering the donor's questionnaire, their physical examination and hemoglobin (Hb\%) estimation. 122,006 blood units from the selected donors were collected over a period of ten years (1st January 2004 to 31st December 2013). These donors were Voluntary Donors (VD) and Replacement Donors (RD). Replacement donors were those donors who donated blood for ailing patients and were family members, close relatives and friends of recipient. The Voluntary donations were obtained from walk in donors and in voluntary blood donation camps organized by different institutions, neighbouring colleges, different social and political organizations. Professional and paid donors were carefully eliminated. Written consent from the donor was also taken prior to donation.

$3 \mathrm{ml}$ blood in plain vial and $2 \mathrm{ml}$ blood in EDTA (ethylene diamine tetra acetic acid) vial taken from the satellite bag. All samples were screened for Hepatitis B surface antigen (HbsAg), Human immunodeficiency virus (HIV), Hepatitis C virus (HCV), Syphilis and Malaria. All tests were performed with commercially available ELISA kits and Rapid card methods as mentioned below.

Tests performed and their specifications

1) HIV antibodies detection: Microlisa HIV for HIV 1 \& 2 (J. Mitra \& Co. Pvt. Ltd.)

2) HCV antibodies detection: Microlisa $3^{\text {rd }}$ generation (J. Mitra \& Co. Pvt. Ltd.)

3) HbsAg antigen detection: Elisa Kit (J. Mitra \& Co. Pvt. Ltd.)

4) HIV rapid card: HIV BI-DOT (J. Mitra \& Co. Pvt. Ltd.)

5) HCV rapid card: HCV BI-DOT (J. Mitra \& Co. Pvt. Ltd.) 
6) HbsAg rapid card; HEPACARD (J. Mitra \& Co. Pvt. Ltd.)

7) Syphilis: Rapid Plasma Reagin (RPR) for syphilis (Span diagnostics)

8) Malaria: Card method (PAN Malaria card by J. Mitra) one step rapid

Immunochromatographic test for $P$. falciparum \& $P$. vivax.

Manufacturer instructions were followed strictly. All reactive samples were repeated in duplicate before labeling them seropositive. Serovigilance of all the test results was performed by State Reference Laboratory (SRL), Department of Microbiology, G. R. Medical College, Gwalior. The blood unit was discarded as per guidelines of NACO whenever the pilot donor samples were found positive for any TTI. The study was divided in two groups; Group “A” (from 2004 to 2008, 5 years) and Group "B” (from 2009 to 2013, 5 years). Both group data were analyzed and compared to observe the trends of transfusion transmitted Infections over a period of 10 years among the donors in Gwalior region i.e. Central India. Study was approved by ethical committee of Gajra Raja Medical College, Gwalior.

\section{Results}

Blood from 122,006 apparently healthy donors aging 18 - 60 years was collected during the study period. Male to Female donor's ratio in the study was 96.2\% $(117,369)$ and 3.8\% (4637) (Figure 1). In 10 years study 79,750 (65.3\%) were voluntary donor while 42,256 (34.7\%) were replacement donors (Table 1 ). Increasing pattern ( $\uparrow$ ) in voluntary donation was observed (Figure 2).

The seropositivity of TTIs in the study was 3.26\% (3985/122,006), while in Group "A" (2004-2008) and in Group "B" (2009-2013) it was 2.25\% $(1238 / 54,874)$ and 4.09\% $(2747 / 67,123)$ respectively (Figure 3). In Group "A" seroprevalence of HIV, HBV, HCV, Syphilis and Malaria was 0.29\% (164 units), 1.16\% (637 units), 0.61\% (335 units), 0.06\% (38 units), 0.11\% (64 units) (Table 2) and in Group "B" it was 0.13\% (91 units), 3.51\% (2360 units), 0.24\% (161 units), 0.17\% (114 units), 0.03\% (21 units) respectively (Table 3). Comparative trends in seroprevalance of TTIs, HBV, HIV, HCV, Syphilis and Malaria in both the group (Group "A" \& "B") is shown in Figure 4. In entire study only two donors in Group "A" had VDRL positive along with HBV and the result of VDRL had been omitted for the convenience of statistic calculations.

When comparing both "A" \& "B" study group the significantly increasing trends $(\uparrow)$ of seroprevalence were

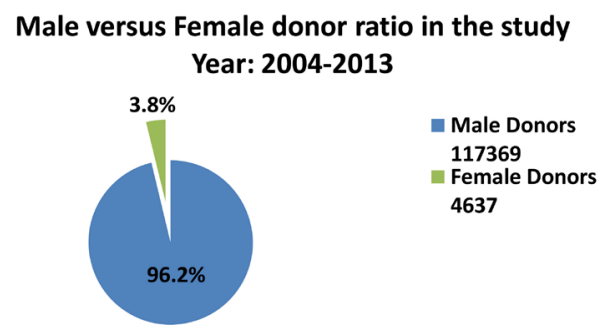

Figure 1. Male to female ratio..

Table 1. Voluntary and relative donors-year 2004 to 2013.

\begin{tabular}{cccc}
\hline Year & Total Blood Donors & Voluntary Blood Donors & Replacement Blood Donors \\
2004 & 7900 & $1201(15.2 \%)$ & $6699(84.8 \%)$ \\
2005 & 8201 & $1254(15.3 \%)$ & $6947(84.7 \%)$ \\
2006 & 11,366 & $2528(22.7 \%)$ & $8838(77.3 \%)$ \\
2007 & 14,461 & $5580(38.5 \%)$ & $8881(61.5 \%)$ \\
2008 & 12,946 & $7878(60.8 \%)$ & $5068(39.2 \%)$ \\
2009 & 12,914 & $11,788(91.3 \%)$ & $1126(8.7 \%)$ \\
2010 & 12,638 & $11,449(90.6 \%)$ & $1189(9.4 \%$ \\
2011 & 13,106 & $11,886(90.7 \%)$ & $1220(9.3 \%)$ \\
2013 & 14,001 & $12,573(89.8 \%)$ & $1428(10.2 \%)$ \\
Total (10 Years) & 14,473 & $13,613(94.0 \%)$ & $\mathbf{4 2 , 2 5 6}(\mathbf{3 4 . 7 \% )}$ \\
\end{tabular}




\section{Voluntary versus Replacement Donors}

Year: 2004-2013

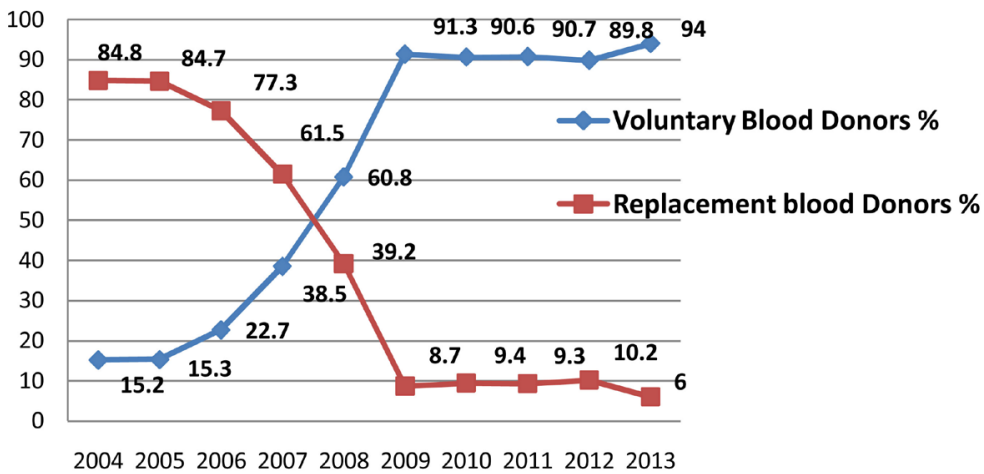

Figure 2. Increasing trends in voluntary blood donation.

Seroprevalence Of TTls in \%

- Group A : 2004-8 ( 5 Yrs.)

Group B : 2009-13 (5Yrs.)

In Entire Study: 2004-13 (10 Yrs)

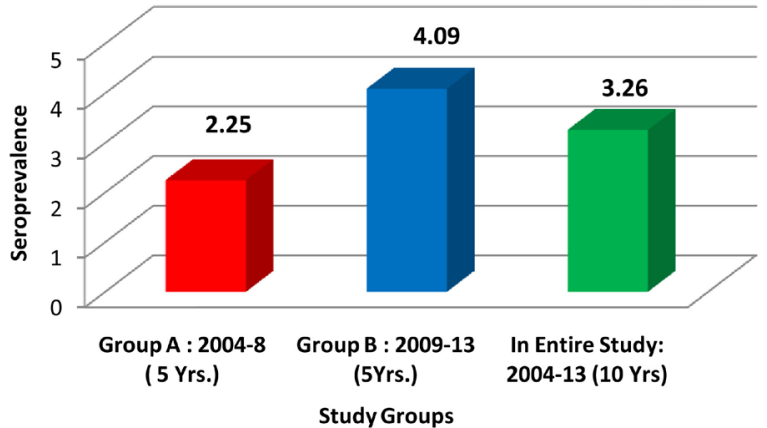

Figure 3. Seroprevalence of TTIs in different groups.

Table 2. Seroprevalence of transfusion transmitted infections in Group “A”. Year: 2004-8.

\begin{tabular}{|c|c|c|c|c|c|c|c|}
\hline Year & blood donors tested & HIV Reactive & HbsAg Reactive & HCV Reactive & VDRL Reactive & MP Positive & TTI Positive \\
\hline 2004 & 7900 & $\begin{array}{c}28 \\
(0.35 \%)\end{array}$ & $\begin{array}{c}69 \\
(0.87 \%)\end{array}$ & $\begin{array}{c}72 \\
(0.91 \%)\end{array}$ & $\begin{array}{c}9 \\
(0.11 \%)\end{array}$ & $\begin{array}{c}16 \\
0.20 \%)\end{array}$ & $\begin{array}{c}194 \\
(2.45 \%)\end{array}$ \\
\hline 2005 & 8201 & $\begin{array}{c}30 \\
(0.36 \%)\end{array}$ & $\begin{array}{c}73 \\
(0.89 \%)\end{array}$ & $\begin{array}{c}75 \\
(0.91 \%)\end{array}$ & $\begin{array}{c}8 \\
(0.09 \%)\end{array}$ & $\begin{array}{c}14 \\
(0.17 \%)\end{array}$ & $\begin{array}{c}200 \\
(2.43 \%)\end{array}$ \\
\hline 2006 & 11,366 & $\begin{array}{c}33 \\
(0.29 \%)\end{array}$ & $\begin{array}{c}83 \\
(0.73 \%)\end{array}$ & $\begin{array}{c}82 \\
(0.72 \%)\end{array}$ & $\begin{array}{c}7 \\
(0.06 \%)\end{array}$ & $\begin{array}{c}14 \\
(0.12 \%)\end{array}$ & $\begin{array}{c}219 \\
(1.92 \%)\end{array}$ \\
\hline 2007 & 14,461 & $\begin{array}{c}48 \\
(0.33 \%)\end{array}$ & $\begin{array}{c}157 \\
(1.08 \%)\end{array}$ & $\begin{array}{c}65 \\
(0.44 \%)\end{array}$ & $\begin{array}{c}9 \\
(0.06 \%)\end{array}$ & $\begin{array}{c}11 \\
(0.07 \%)\end{array}$ & $\begin{array}{c}290 \\
(2.00 \%)\end{array}$ \\
\hline 2008 & 12,946 & $\begin{array}{c}25 \\
(0.19 \%)\end{array}$ & $\begin{array}{c}255 \\
(1.96 \%)\end{array}$ & $\begin{array}{c}41 \\
(0.31)\end{array}$ & $\begin{array}{c}5 \\
(0.03 \%)\end{array}$ & $\begin{array}{c}9 \\
(0.06 \%)\end{array}$ & $\begin{array}{c}335 \\
(2.58 \%)\end{array}$ \\
\hline Five Year & 54,874 & $\begin{array}{c}164 \\
(0.29 \%)\end{array}$ & $\begin{array}{c}637 \\
(1.16 \%)\end{array}$ & $\begin{array}{c}335 \\
(0.61 \%)\end{array}$ & $\begin{array}{c}38 \\
(0.06 \%)\end{array}$ & $\begin{array}{c}64 \\
(0.11 \%)\end{array}$ & $\begin{array}{c}1238 \\
(2.25 \%)\end{array}$ \\
\hline
\end{tabular}

reported in TTIs (from 2.25 to 4.09\%) ( $p=0.000001$ ), HBV (From 1.16 to 3.15\%) ( $p=0.000001$ ) and Syphilis (from $0.06 \%$ to $0.17 \%)(p=0.04809$ ) while decreasing trends $(\downarrow)$ were observed in HIV (from $0.29 \%$ to $0.13 \%$ ), HCV (from $0.61 \%$ to $0.24 \%$ ) and Malaria (from $0.11 \%$ to $0.03 \%$ ) (Table 2 \& Table 3, Figure 4). Data has been compared statistically by frequency distribution and percentage proportion. Chi square $\left(\mathrm{X}^{2}\right)$ test was applied to know the significant ( $p$ value) ratio of difference statistically. 
Table 3. Seroprevalence of transfusion transmitted infections in Group “B”. Year: 2009-13.

\begin{tabular}{|c|c|c|c|c|c|c|c|}
\hline Year & Blood donors tested & HIV Reactive & HbsAg Reactive & HCV Reactive & VDRL Reactive & MP Positive & TTI Positive \\
\hline 2009 & 12,914 & $\begin{array}{c}20 \\
(0.15 \%)\end{array}$ & $\begin{array}{c}514 \\
(3.98 \%)\end{array}$ & $\begin{array}{c}47 \\
(0.36 \%)\end{array}$ & $\begin{array}{c}12 \\
(0.09 \%)\end{array}$ & $\begin{array}{c}7 \\
(0.05 \%)\end{array}$ & $\begin{array}{c}600 \\
(4.64 \%)\end{array}$ \\
\hline 2010 & 12,638 & $\begin{array}{c}16 \\
(0.12 \%)\end{array}$ & $\begin{array}{c}488 \\
(3.86 \%)\end{array}$ & $\begin{array}{c}46 \\
(0.36 \%)\end{array}$ & $\begin{array}{c}18 \\
(0.14 \%)\end{array}$ & $\begin{array}{c}3 \\
(0.02 \%)\end{array}$ & $\begin{array}{c}571 \\
(4.51 \%)\end{array}$ \\
\hline 2011 & 13,106 & $\begin{array}{c}17 \\
(0.12 \%)\end{array}$ & $\begin{array}{c}441 \\
(3.36 \%)\end{array}$ & $\begin{array}{c}20 \\
(0.15 \%)\end{array}$ & $\begin{array}{c}28 \\
(0.21 \%)\end{array}$ & $\begin{array}{c}3 \\
(0.02 \%)\end{array}$ & $\begin{array}{c}509 \\
(3.88 \%)\end{array}$ \\
\hline 2012 & 14,001 & $\begin{array}{c}25 \\
(0.17 \%)\end{array}$ & $\begin{array}{c}476 \\
(3.39 \%)\end{array}$ & $\begin{array}{c}22 \\
(0.15 \%)\end{array}$ & $\begin{array}{c}25 \\
(0.17 \%)\end{array}$ & $\begin{array}{c}4 \\
(0.02 \%)\end{array}$ & $\begin{array}{c}552 \\
(3.94 \%)\end{array}$ \\
\hline 2013 & 14,473 & $\begin{array}{c}13 \\
(0.09 \%)\end{array}$ & $\begin{array}{c}441 \\
(3.04 \%)\end{array}$ & $\begin{array}{c}26 \\
(0.17 \%)\end{array}$ & $\begin{array}{c}31 \\
(0.21 \%)\end{array}$ & $\begin{array}{c}4 \\
(0.02 \%)\end{array}$ & $\begin{array}{c}515 \\
(3.55 \%)\end{array}$ \\
\hline Five Year & 67,132 & $\begin{array}{c}91 \\
(0.13 \%)\end{array}$ & $\begin{array}{c}2360 \\
(3.51 \%)\end{array}$ & $\begin{array}{c}161 \\
(0.24 \%)\end{array}$ & $\begin{array}{c}114 \\
(0.17 \%)\end{array}$ & $\begin{array}{c}21 \\
(0.03 \%)\end{array}$ & $\begin{array}{c}2747 \\
(4.09 \%)\end{array}$ \\
\hline
\end{tabular}

Trends of Sroprevalence of TTIs

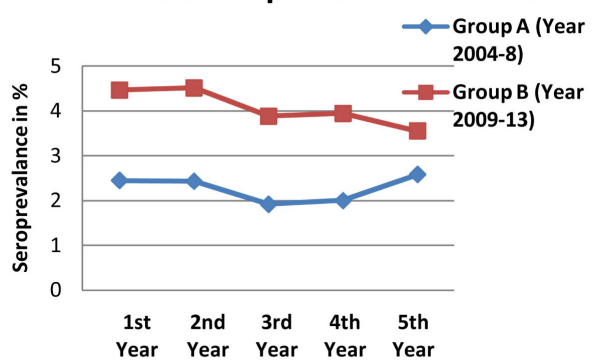

Trends of Seroprevalance of HIV

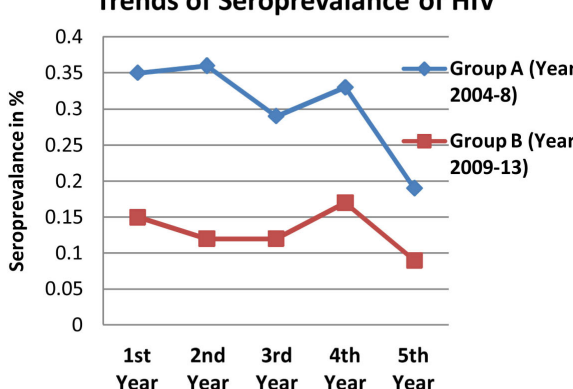

Trends of seroprevalence of Syphilis

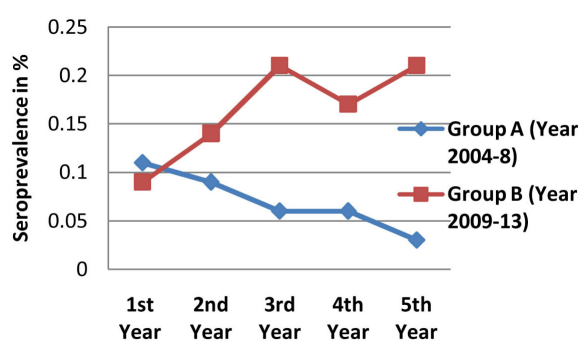

\section{Trends of Seroprevalence Of HBV}

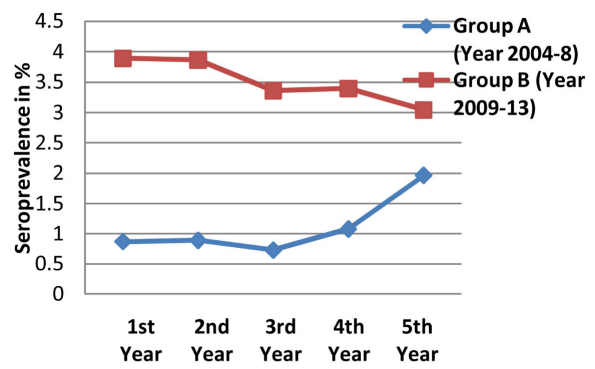

Trends of seroprevalence of HCV

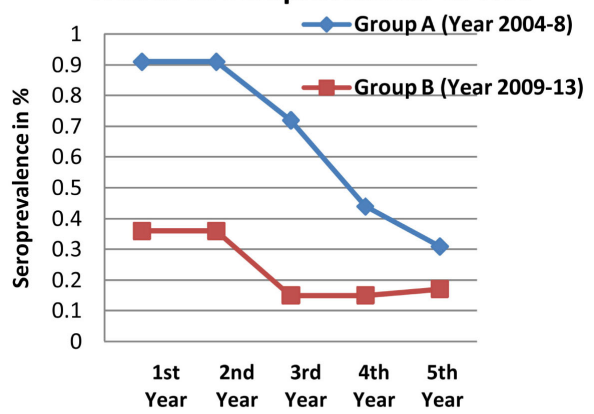

Trends of Positivity of Malaria

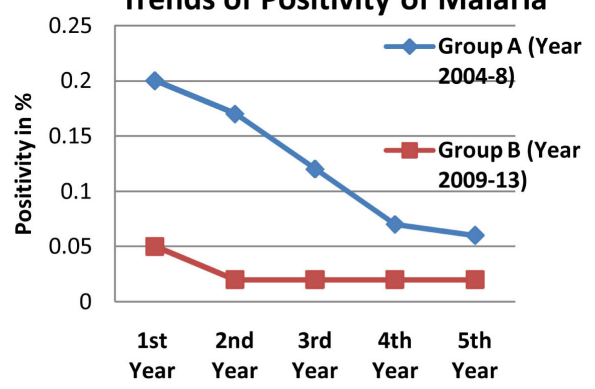

Figure 4. Trends of seroprevalence of TTIs, HBV, HIV, HCV, Syphilis and Malaria.

\section{Discussion}

Transfusion of blood and blood component is a life saving procedure and help innumerable people worldwide 
but at the same time blood transfusion is an important mode of transmission of infections to the recipients. In the developing countries the prevalence of TTIs is much higher and quite far from attending a zero risk level at present moment [1]. These are transmitted parenterally, vertically or through high risk sexual behavior and can cause acute and chronic life threatening disorders [13] [14].

In present study voluntary donors constituted $65.3 \%$ and replacement donors were $34.7 \%$. Data showed the increasing pattern from the year 2004 (15.2\%) to 2013 (94\%) in voluntary donation. These findings are similar to the study done by Gupta P.K. et al. [15] and Pallavi P. et al. [16]. Increase in voluntary donors may be attributed to the increasing public awareness and involvement of Government bodies like NACO that actively propagate voluntary blood donation in our country while previous studies have reported high percentage of replacement donors; 94.7\% [17], 99.48\% [18] and 82.4\% [19]. As compare to first five years (54,874 units) donations, last five years (67,123 units) donations were increased by $22.3 \%$ due to general awareness in the society and various national blood donation programmes. Male to female donor's ratio in the study was $96.2 \%(117,369)$ and 3.8\% (4627). Low turnouts of female donors were because of traditional thinking of Indian society as well as females in India are generally underweight and anemic according to donor's selection criteria.

Overall prevalence of TTIs in the study was 3.26\% while in first five years (Group "A") it was $2.25 \%$ and last five years (Group "B") it was $4.09 \%$ showing an increasing pattern. The prevalence of TTIs among Indian blood donors is ranging as; $\mathrm{HBV}-0.66 \%$ to $12 \%$, $\mathrm{HCV}-0.5 \%$ to $1.5 \%$, $\mathrm{HIV}-0.08 \%$ to $3.87 \%$ and syphilis $-0.8 \%$ to $3 \%$ [20]. With every unit of blood there is $1 \%$ chance of transfusion associated problems including TTIs [21]. The risk of TTIs has decreased in developed countries over the past two decades, primarily because of extraordinary success in preventing HIV and other established transfusion transmitted viruses from entering the blood supply [22]. But same may not hold good for the developing countries like India. As in our study TTIs is increased from $2.25 \%$ to $4.09 \%$. The national policy for blood transfusion services in our country is of recent origin and the transfusion services are hospital based and fragmented [15].

The seropositivity of HBV in Group "A" donors was $1.16 \%$ and is significantly increased in recent years in Group "B" donors 3.51\% comparable to the study from Rajasthan 3.44\% [23] while low HbsAg prevalence rate was reported in Punjab blood donors 1.7\% [24], Delhi-2.23\% [18], coastal area of Karnataka—0.62\% [25], Bangalore-1.86\% [26] and Mysore-1.27\% [16]. Seropositivity is higher in the present study, it may be because of use of common syringes in the medical treatment in rural areas is still prevailing and use of sensitive tests for TTIs in our blood bank setup. Prevalence of HBV is low in developed countries $(0.1 \%-0.5 \%)$, it is high (5\% - 15\%) in South East Asia and China [18] and towering in African countries; Nigeria-18.6\% [27], Tanzania-11\% [28] and West Africa-13.4\% [29].

The seroposittivity of HIV was $0.29 \%$ in Group "A" and it was $0.13 \%$ in Group "B", showing decreasing pattern comparable with the findings of Das B.K. et al. 0.19\% [30]. In India it ranges from $0.2 \%$ to $1 \%$ [31] [32] whereas reported high in rural India $2.11 \%$ [33]. The prevalence of HIV in various parts of India is different with high rating in Western India 0.47\% [34] and Southern India 0.44\% [16] while in Punjab, North India it is $0.26 \%$ [35]. NACO suggested an overall prevalence of $0.91 \%$ (2005) in India with $0.25 \%$ in Delhi [18]. For HIV, India is second only to South Africa in terms of overall number of people living with HIV. In West Africa it is $1.8 \%$ [30], 6\% in Nigeria [27] and 8.7\% in Tanzania [28].

Decreasing pattern of seroprevalence of HCV is reported in our study from $0.61 \%$ in Group "A" to $0.24 \%$ in Group "B" which is similar to study done by Pallavi P. et al. 0.23\% [16] and Col J. Philip et al. 0.22\% [36] while high seroprevalnce was reported by Bagga P.K. et al. 0.88\% [37], Chattoraj A. et al. 0.79\% [20] and Kaur H. et al. 0.78\% [25] but it is higher in African countries; West Africa 6.3\% [29], Tanzania 8\% [28]. In USA \& Europe range is $0.9 \%$ to $1.4 \%$ [38] [39].

Increasing pattern in seropositivity of syphilis from $0.06 \%$ (Group A) to $0.17 \%$ (Group B) was reported in our study. In others Indian subcontinent studies it is seen to be $0.01 \%$ [40], 0.07\% [6], 0.85\% [41] and $1.2 \%$ [42].

Decreasing pattern in positivity of Malaria from $0.11 \%$ (Group A) to $0.03 \%$ (Group B) was reported in our study. A study shows that a rate of transfusion transmitted malaria varies from less than 0.2 in non-endemic countries to 50 or more cases per million in endemic countries as discussed by Mollison et al. [43]. In other parts of India it is $0.09 \%$ [ 40$]$ and $0.01 \%$ [1].

Goal of any transfusion service is to provide safe blood to the recipients and one should be as close as possible to achieve zero risk level. Availability of safe blood for transfusion is a must for the recipients as well for community and can be achieved by vigorous and cautious screening of donors along with testing of donated 
blood with more advanced laboratory screening tests and we have already started opting these precautions on priority basis.

\section{Conclusion}

Our study showed increasing trend of voluntary blood donation with male predominance. Amongst the blood donors, seropositivity of HbsAg was highest followed by HCV, syphilis, HIV and Malaria. High seropositivity with significantly increasing trend of HbsAg was observed in the study. It needs further investigation including studying the prevalence rate of HBV in the general population to address the issue. Decreasing trends with low prevalence of HIV and HCV observed in the study is an encouraging sign supporting the growing awareness of these life threatening diseases. Malaria and VDRL appears to be sporadic findings and detection is mainly based on available sensitive kits. So we conclude that substantial risk of transfusion-transmissible infections is still prevailing with the blood transfusion services and ensuring that blood safety has a long way to go.

\section{Acknowledgements}

The author(s) are grateful to Dr. G.S. Patel, Head of the Institute: Dean G.R. Medical College, Gwalior and Dr. (Mrs.) Jyoti Bindal, Superintendent, J. A. Hospital, Gwalior for their kind cooperation and unstinted support without which this study would have not been possible. The author(s) also acknowledge with deep gratitude the invaluable assistance received from Dr. Manohar Bhatiya, Resident (PSM), G. R. M. C. Gwalior, Mrs. Mala Bhadoriya and Mrs. Neetu Suryvanshi, technicians blood bank, J. A. Hospital, Gwalior.

\section{References}

[1] Fernandes, H., D’souza, P.F. and D’souza, P.M. (2010) Prevalence of Transfusion Transmitted Infections in Voluntary and Replacement Donors. Indian Journal of Hematology \& Blood Transfusion, 26, 89-91.

http://dx.doi.org/10.1007/s12288-010-0044-0

[2] Widman, F.K. (ed.) (1985) Technical Manual. American Association of Blood Banks, Arlington, 325-344.

[3] World Health Organization (WHO) (2002) Blood Safety Strategy for the African Region. World Health Organization, Regional Office for Africa (WHO AFR/RC51/9 Rev.1), Brazzaville.

[4] World Health Organization (WHO) (2007) Status of Blood Safety in the WHO African Region: Report of the 2004 Survey WHO Regional Office for Africa. World Health Organization, Brazzaville, 1-25.

[5] Kitchen, A.D. and Barbara, J.A.J. (2001) Transfusion Transmitted Infections. In: Murphy, M.F. and Pamphilon, D.H., Eds., Practical Transfusion Medicine, Blackwell Science, Oxford, 192-210.

[6] Giri, P.A., Deshpande, J.D., Phalke, D.B. and Karle, L.B. (2012) Seroprevalence of Transfusion Transmissible Infections among Voluntary Blood Donors at a Tertiary Care Teaching Hospital in Rural Area of India. Journal of Family Medicine and Primary Care, 1, 48-51.

[7] Nancy Singh (2011) NAT: Safe Blood, Safe India. http://www.expresshealthcare.in/200810/knowledge02.shtml

[8] Grgicević, D., Balija, M., Pirc-Tiljak, D., Mihaljević, I., Gjenero-Margan, I., Zupancić-Salek, S. and Macek, P. (2000) Decreasing Risk of Viral Transfusion-Transmitted Diseases in Croatia. Croatian Medical Journal, 41, 191-196.

[9] Mujeeb, S.A., Kausar, A. and Khalid, M. (2000) Seroprevalence of HBV, HCV, and HIV Infection among College Going Voluntary Donors. Journal Pakistan Medical Association, 50, 269-270.

[10] Kar, H.K. (2009)Global and National Overview of HIV/AIDS Epidemic. In: Sharma, V.K., Ed., Sexually Transmitted Diseases and HIV/AIDS, 2nd Edition, Viva Books Pvt. Ltd, New Delhi, 99-109.

[11] Lavanchy, D. (2004) Hepatitis B Virus Epidemiology, Disease Burden, Treatment, and Current and Emerging Prevention and Control Measures: A Review. Journal of Viral Hepatitis, 11, 97-107. http://dx.doi.org/10.1046/j.1365-2893.2003.00487.x

[12] Bhattacharya, P., Chandra, P.K., Datta, S., Banerjee, A., Chakraborty, S., Rajendran, K., Basu, S.K., Bhattacharya, S.K. and Chakravarty, R. (2007) Significant Increase in HBV, HCV, HIV and Syphilis Infections among Blood Donors in West Bengal, Eastern India 2004-2005: Exploratory Screening Reveals High Frequency of Occult HBV Infection. World Journal of Gastroenterology, 13, 3730-3733.

[13] Irshad, M. and Peter, S. (2002) Spectrum of Viral Hepatitis in Thalassemic Children Receiving Multiple Blood Transfusions. Indian Journal of Gastroenterology, 21, 183-184.

[14] Mollah, A.H., Nahar, N., Siddique, M.A., Anwar, K.S., Hassan, T. and Azam, M.G. (2003) Common TransfusionTransmitted Infectious Agents among Thalassaemic Children in Bangladesh. Journal of Health, Population and Nutri- 
tion, 21, 67-71.

[15] Gupta, P.K., Kumar, H., Basannar, D.R. and Jaiprakash, M. (2006) Transfusion Transmitted Infections in Armed Forces: Prevalence and Trends. Medical Journal Armed Forces India, 62, 348-350.

[16] Pallavi, P., Ganesh, C.K., Jayashree, K. and Manjunath, G.V. (2011) Seroprevalence and Trends in Transfusion Transmitted Infections among Blood Donors in a University Hospital Blood Bank: A 5 Year Study. Indian Journal of Hematology and Blood Transfusion, 27, 1-6. http://dx.doi.org/10.1007/s12288-010-0047-x

[17] Kakkar, N., Kaur, R. and Dhanoa J. (2004) Voluntary Donors—Need for a Second Look. Indian Journal of Pathology and Microbiology, 47, 381-383.

[18] Pahuja, S., Sharma, M., Baitha, B. and Jain, M. (2007) Prevalence and Trends of Markers of Hepatitis C Virus, Hepatitis B Virus and Humany Immunodeficiency Virus in Delhi Blood Donors. A Hospital Based Study. Japanese Journal of Infectious Diseases, 60, 389-391.

[19] Singh, B., Verma, M., Kotru, M., Verma, K. and Batra, M. (2005) Prevalence of HIV and VDRL Seropositivity in Blood Donors of Delhi. Indian Journal of Medical Research, 122, 234-236.

[20] Chattoraj, A., Bhel, R. and Kataria, V. (2008) Infectious Disease Markers in Blood Donors. Medical Journal Armed Forces India, 64, 33-35. http://dx.doi.org/10.1016/S0377-1237(08)80142-6

[21] Arora, D., Arora, B. and Khetarpal, A. (2010) Seroprevalence of HIV, HBV, HCV and Syphilis in Blood Donors in Southern Haryana. Indian Journal of Pathology and Microbiology, 53, 308-309. http://dx.doi.org/10.4103/0377-4929.64295

[22] Fiebig, E.W. and Busch, M.P. (2004) Emerging Infections in Transfusion Medicine. Clinics in Laboratory Medicine, 24, 797-823. http://dx.doi.org/10.1016/j.cll.2004.05.009

[23] Garg, S., Mathur, D.R. and Gard, D.K. (2001) Comparison of Seropositivity of HIV, HBV, HCV and Syphilis in Replacement and Voluntary Blood Donors in Western India. Indian Journal of Pathology and Microbiology, 44, 409-412.

[24] Kaur, H., Dhanon, J. and Pawar, G. (2001) Hepatitis C infection amongst Blood Donors in Punjab—A Six Year Study. Indian Journal of Hematology and Blood Transfusion, 19, 21-22.

[25] Singh, K., Bhat, S. and Shastry, S. (2009) Trend in Seroprevalence of Hepatitis B Virus Infection among Blood Donors of Coastal Karnataka, India. Journal of Infection in Developing Countries, 3, 376-379.

[26] Srikrishna, A., Sitalakshmi, S. and Damodar, P. (1999) How Safe Are Our Safe Donors. Indian Journal of Pathology and Microbiology, 42, 411-416.

[27] Buseri, F.I., Muhibi, M.A. and Jeremiah, Z.A. (2009) Sero-Epidemiology of Transfusion-Transmissible Infectious Diseases among Blood Donors in Osogbo, South-West Nigeria. Blood Transfusion, 7, 293-299.

[28] Mecky, I.N., Magesa, P.M. and Lyamuya, E.F. (2006) Seroprevalence of Human Immunodeficiency Virus, Hepatitis B and $\mathrm{C}$ Viruses and Syphilis Infections among Blood Donors at the Muhimbili National Hospital in Dar Es Salaam, Tanzania. BMC Public Health, 6, 21. http://www.biomedcentral.com/1471-2458/6/21 http://dx.doi.org/10.1186/1471-2458-6-21

[29] Nagalo, B.M., Bisseye, C., Sanou, M., Kienou, K., Nebié, Y.K., Kiba, A., Dahourou, H., Ouattara, S., Nikiema, J.B., Moret, R., Zongo, J.D. and Simpore, J. (2012) Seroprevalence and Incidence of Transfusion-Transmitted Infectious Diseases among Blood Donors from Regional Blood Transfusion Centres in Burkina Faso, West Africa. Tropical Medicine \& International Health, 17, 247-253. http://dx.doi.org/10.1111/j.1365-3156.2011.02902.x

[30] Das, B.K., Gayen, B.K., Aditya, S., Chakrovorty, S.K., Datta, P.K. and Joseph, A. (2011) Seroprevalence of Hepatitis B, Hepatitis C, and Human Immunodeficiency Virus among Healthy Voluntary First-Time Blood Donors in Kolkata. Annals of Tropical Medicine and Public Health, 4, 86-90.

[31] Sharma, R.R., Cheema, R., Vajpayee, M., Rao, U., Kumar, S., Marwaha, N., et al. (2004) Prevalence of Markers of Transfusion Transmissible Diseases in Voluntary and Replacement Blood Donors. National Medical Journal of India, 17, 19-21.

[32] Paramjit, K. and Basu, S. (2005) Transfu Sion-Transmitted Infections: Existing and Emerging Pathogens. Journal of Post Graduate Medicine, 51, 146-151.

[33] Sonwane, B.R., Birare, S.D. and Kulkarni, P.V. (2003) Prevalence of Seroreactivity among Blood Donors in Rural Population. Indian Journal of Medical Sciences, 57, 405-407.

[34] Joshi, S.R. (1988) Seropositivity Status for HIV Infection among Voluntary and Replacement Blood Donors in the City of Surat from Western India. Indian Journal of Hematology and Blood Transfusion, 16, 20-21.

[35] Kaur, H., Dhanoa, J. and Pawar, G. (2001) Hepatitis C Infection amongst Blood Donors in Punjab-A Six Year Study. Indian Journal of Hematology and Blood Transfusion, 19, 21-22.

[36] Philip, J., Sarkar, R.S., Kumar, S. and Pathak A. (2012) Changing Trends of Transfusion Transmitted Viral Infections among Blood Donors in the Last Decade-A 10-Year Study in a Large Tertiary Care Blood Bank (2000-2009). Medi- 
cal Journal Armed Forces India, 68, 28-32.

[37] Bagga, P.K. and Singh, S.P. (2007) Seroprevalence of Hepatitis C Antibodies in healthy Blood Donors-A Prospective Study. Indian Journal of Pathology and Microbiology, 50, 429-432.

[38] Stevens, C.E., Taylor, P.E., Pindyck, J., Choo, Q.L., Bradley, D.W., Kuo, G. and Houghton M. (1990) Epidemiology of Hepatitis C Virus. A Preliminary Study in Volunteer Blood Donors. Journal of the American Medical Association, 263, 49-53. http://dx.doi.org/10.1001/jama.1990.03440010047028

[39] Sharara, A.I., Hunt, C.M. and Hamilton, J.D. (1996) Hepatitis C. Annals of Internal Medicine, 125, 658-668. http://dx.doi.org/10.7326/0003-4819-125-8-199610150-00006

[40] Chandra, T., Rizvi, S.N.F. and Agarwal, D. (2014) Decreasing Prevalence of Transfusion Transmitted Infection in Indian Scenario. The Scientific World Journal, 2014, Article ID: 173939. http://dx.doi.org/10.1155/2014/173939

[41] Gupta, N., Kumar, V. and Kaur, A. (2004) Seroprevalence of HIV, HBV, HCV and Syphilis in Voluntary Blood Donors. Indian Journal of Medical Sciences, 58, 255-257.

[42] Mumtaz, S., Rehman, M.U., Muzaffar, M., Hassan, M.U. and Iqbal, W. (2002) Frequency of Seropositive Blood Donors for Hepatitis B, C and HIV Viruses in Railway Hospital, Rawalpindi. Pakistan Journal of Medical Research, 41, 19-22.

[43] Mollison, P.L., Engelfriet, C.P. and Contreras, M. (1997) Blood Transfusion in Clinical Medicine. Blackwell Sciences, Hoboken. 
Scientific Research Publishing (SCIRP) is one of the largest Open Access journal publishers. It is currently publishing more than 200 open access, online, peer-reviewed journals covering a wide range of academic disciplines. SCIRP serves the worldwide academic communities and contributes to the progress and application of science with its publication.

Other selected journals from SCIRP are listed as below. Submit your manuscript to us via either submit@scirp.org or Online Submission Portal.
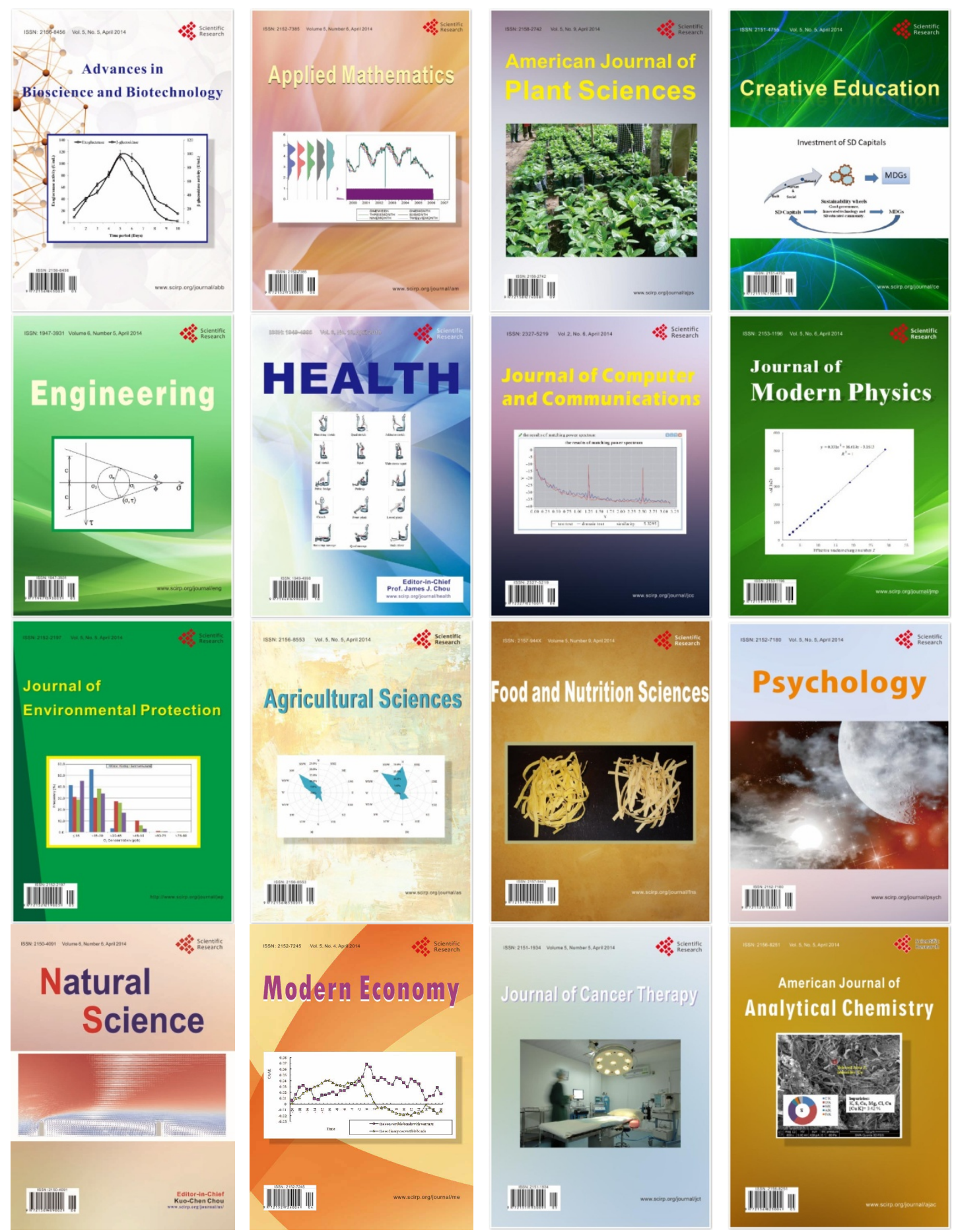